\title{
Utilization of Agro-Wastes to Produce Oyster Mushroom (Pleurotus ostreatus) with High Antioxidant and Antimicrobial Activities
}

\author{
Amal M. Abd El-Razek', Amel Ibrahim², Aisha Elattar ${ }^{2}$ and Dalal Asker ${ }^{1,3}$ \\ ${ }^{1}$ Food Science and Technology Dept., Faculty of Agric., Alexandria University 21545, \\ El-Shatby, Alexandria, Egypt. \\ ${ }^{2}$ Dairy Science and Technology Dept., Faculty of Agric., Alexandria University 21545, \\ El-Shatby, Alexandria, Egypt. \\ ${ }^{3}$ Department of Materials Science \& Engineering, University of Toronto, Toronto, ON, Canada.
}

Received: 14 January, 2020

Revised: 10 March, 2020

Accepted: 1 April, 2020

\begin{abstract}
Oyster mushroom (Pleurotus ostreatus) is a good source of bioactive compounds that have numerous health benefits and medicinal properties. In this study, the effect of $P$. ostreatus cultivation in agro-waste substrates on its potential as a food additive with antioxidant and antimicrobial activities was investigated. Extracts of $P$. ostreatus cultivated on mixed rice and wheat straws (RS+WS) substrates showed higher total polyphenols (TPC), total flavonoids (TFC), $\alpha$-tocopherol content, ferric reducing antioxidant power and antibacterial activities than those cultivated on rice straw (RS) alone. The HPLC analysis of their ethanolic extracts revealed 11 phenolic compounds including $p$-hydroxy benzoic acid, naringenin, kaempferol and apigenin as major compounds. The aqueous and ethanolic extracts of both cultivates showed significant antibacterial activity against Salmonella typhimurium, Escherichia coli, and Staphylococcus aureus, while no inhibitory effect on Bacillus cereus was observed. The results indicated that $P$. ostreatus cultivation is an effective bioconversion process that is capable to transfer agro-wastes into potentially valuable source of natural antioxidant and antimicrobial additives for further use in functional food products.
\end{abstract}

Keywords: Agro-waste, oyster mushrooms, antioxidants, antimicrobials, polyphenols, flavonoids.

\section{INTRODUCTION}

Mushrooms are macrofungi with a distinctive fruiting body that is large and visible to the naked eye. For centuries, edible mushrooms have been cultivated and used as food due to their attractive sensory properties, high levels of nutrients and relatively easy cultivation. Mushrooms contain $10-40 \%$ protein, $3-21 \%$ carbohydrates, $3-35 \%$ dietary fibers, $5 \%$ unsaturated fat and a variety of vitamins and minerals ( Roncero-Ramos \& Delgado-Andrade, 2017). Meanwhile, Chang (1996) mentioned that mushrooms have gained popularity as a functional food resource due to their content of several therapeutic compounds that have beneficial health effects.

The oyster mushroom ,Pleurotus ostreatus, is the second cultivated edible mushroom worldwide due to its high nutritional value (high protein, fiber, and carbohydrate contents), unique flavour and aromatic properties ( Iwalokun et al., 2007). The $P$. ostreatus also produces many health-promoting bioactives with antioxidative, antimicrobial, antitu- mor and anti-inflammatory properties (Iwalokun et al., 2007, Parola et al., 2017).The antioxidant effect of $P$. ostreatus and other related species has been correlated with their content of phenolic and flavonoids compounds (Iwalokun et al., 2007, Karaman et al., 2010, Gąsecka et al., 2016). Other antioxidant compounds such as ascorbic acid, glycosides, tocopherols, polysaccharides, ergothioneine and carotenoids are also found in oyster mushroom (Pleurotus spp.), (Iwalokun et al., 2007, Gąsecka et al., 2016). The chemical structure of polyphenols is characterized by the presence of an aromatic ring with hydroxyl groups that exhibit a strong radical scavenger and free radical inhibitor activities (Frei \& Higdon, 2003, Iwalokun et al., 2007). The in vitro and in vivo studies have demonstrated that these bioactive compounds can delay, prevent or reverse oxidative damage to biomolecules as DNA, proteins and lipids, which prevents many chronic diseases including cancer, diabetes and neurodegenerative disorders (Frei \& Higdon, 2003, Iwalokun et al., 2007). The P. ostreatus extracts have broadspectrum of antibacterial activity, which inhibits 
the growth of both Gram positive and Gram negative bacteria.(Iwalokun et al., 2007, Karaman et al., 2010). Increasing consumer awareness about the negative health impact of synthetic food additives as antioxidants and antimicrobial, has increased the demand for natural additives in functional food as foods that are fortified with biologically active ingredients, supplements and medicine. To meet this growing demand, natural bioactive compounds can be extracted from plants, food wastes and fruit fungi such as mushroom (Pandey et al., 2018).

In developing countries, which face challenges due to poverty and shortage of resources and technology, mushroom can be a promising source to combat food insecurity and malnutrition (Pandey et al., 2018). The Pleurotus spp. have many advantages including rapid growth in short time, low cost, minimal chance of disease manifestation, as well as easy adaptation and maintenance (Pandey et al., 2018). They are usually found in tropical and subtropical rainforests where they can colonise and degrade lignocellulosic substrates. The Pleurotus spp. have thus been cultured on agro-wastes such as olive cake, pine needles, wheat straw and banana leaves (Koutrotsios et al., 2018, Pandey et al., 2018).

In Egypt, the estimated annual amount of agricultural wastes ranges from 30 to 35 million dry tonnes, of which about 12 million tons are utilized to produce feed and organic fertilizer (Elfeki et al.,
2017). The remaining plant wastes are incinerated or disposed in landfills resulting in environmental pollution and escalating rates of carbon dioxide and other gases that contribute to global warming (Sharma et al., 2013). This huge amount of agrowastes can be beneficially utilized in mushroom cultivation, a biotransformation of wastes into food and a remedy for pollution.

In previous work, Elattar et al.(2019) showed that the yield and overall acceptability of $P$. ostreatus were higher when grown on rice straw (RS) or rice and wheat straws (RS+WS) 1:1 (w/w) compared to those grown on other substrates such as saw dust and water hyacinth alone or mixed with wheat straw 1:1 (w/w). The main objective of the present study was to investigate the effect of $P$. ostreatus cultivation in two agro-waste substrates on its potential as a food additive with antioxidant and antimicrobial activities (Fig.1). Total polyphenols (TPC) and total flavonoids (TFC) contents were determined by colorimetric assays. Individual phenolic and flavonoid compounds were identified by HPLC. To determine the antimicrobial activities of mushroom extracts against both Gram-positive (Bacillus cereus and Staphylococcus aureus) and Gram-negative (Escherichia coli and Salmonella typhimurium) bacterial strains, two methods were used (agar well diffusion and macro-broth dilution methods).

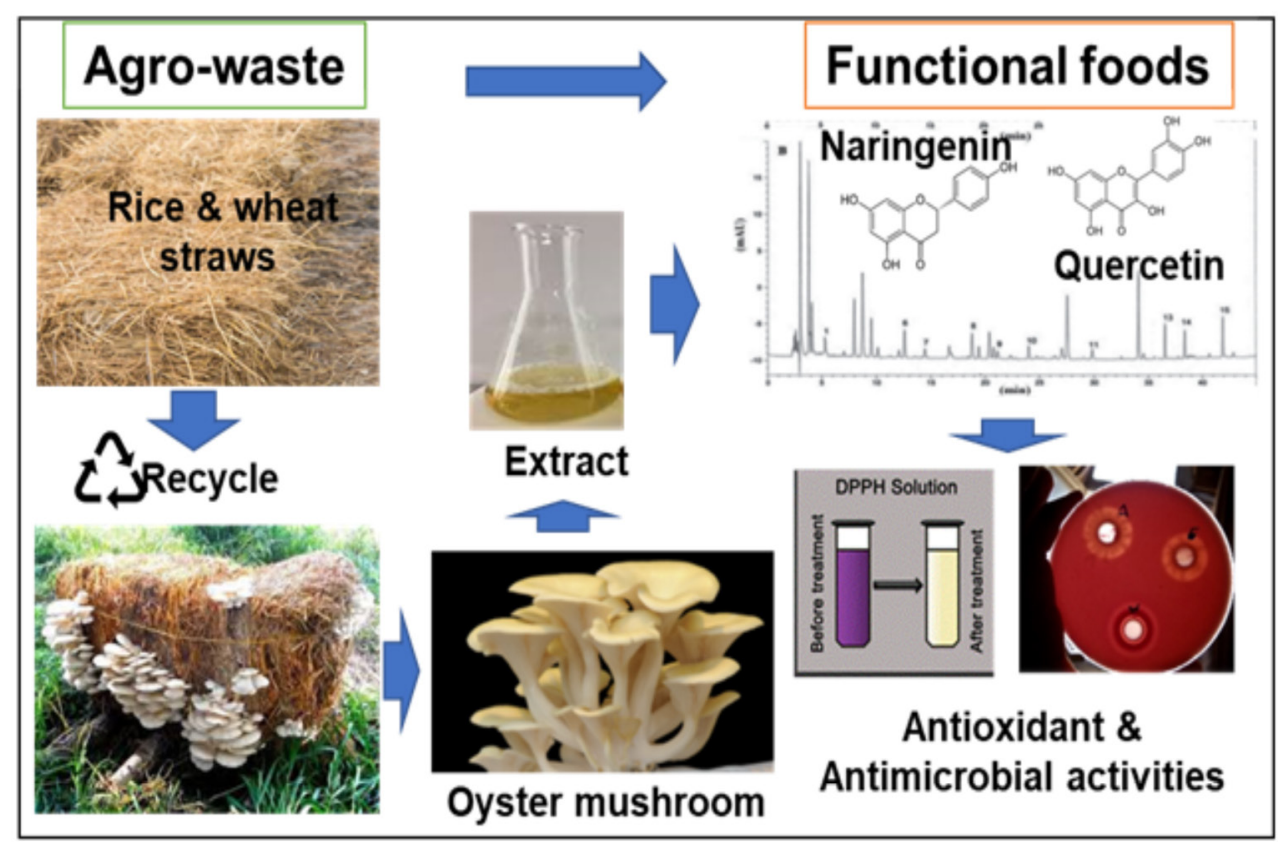

Fig. 1: Effect of $P$. ostreatus cultivation in two agro-waste substrates on its potential as a food additive with antioxidant and antimicrobial activities 


\section{MATERIALS AND METHODS}

\section{Materials:}

\section{Chemicals and reagents}

Dimethyl sulfoxide (DMSO), 2,2-Diphenyl1-picrylhydrazyl (DPPH), $\mathrm{NaNO}_{2}, \mathrm{AlCl}_{3}, \mathrm{Na}_{2} \mathrm{CO}_{3}$, $\mathrm{NaOH}, \mathrm{HNO}_{3}, \mathrm{H}_{2} \mathrm{O}_{2}$, Folin-Ciocalteu phenol reagent, gallic, caffeic, catechol, $p$-hydroxy benzoic acid, caffeine, vanillic acid, syringic acid, vanillin, $p$-coumaric acid, benzoic acid, ferulic acid, ellagic, salicylic acid and cinnamic were purchased from Sigma-Aldrich (St. Louis, MO). Baird parker agar base, egg yolk tellurite emulsion, nutrient agar, violet red bile lactose agar and nutrient broth were obtained from Oxoid, England.

\section{Methods:}

\section{Mushroom cultivation}

The $P$. ostreatus was cultivated on rice straw (RS) or a 1:1 (w/w) mixture of rice and wheat straws (RS+WS), (Elattar et al., 2019). Straws were cut into small pieces (2-3 inches long) and soaked in water at room temperature for $1-2 \mathrm{hr}$, then rinsed with clean water 2-3 times. Their moisture content was also adjusted to $65 \%$. Then, $\mathrm{CaCO}_{3}$ was added at a final concentration of $0.2 \%(\mathrm{w} / \mathrm{w})$ of the total substrate. All substrates were filled into polyethylene bags and autoclaved at $121{ }^{\circ} \mathrm{C}$ for $80 \mathrm{~min}$, then cooled down to room temperature and inoculated with $5 \mathrm{~g}$ spawn of $P$. ostreatus per $100 \mathrm{~g}$ of the substrate wet weight. The inoculated bags were incubated in darkness at $20-25{ }^{\circ} \mathrm{C}$ and $80-95 \%$ relative humidity for 3 weeks until the substrates were completely colonized with mycelium. Bags were punctured from the 4 sides to facilitate primordial initiation.

\section{Preparation of mushroom extracts}

Freshly harvested $P$. ostreatus samples were washed, sliced (2 $\mathrm{mm}$ thickness) and freeze-dried for $24 \mathrm{hr}$. Dried mushroom samples were ground into powder using a mechanical grinder (Moulinex, Germany). About $20 \mathrm{~g}$ of each of the ground samples were extracted with either $200 \mathrm{~mL}$ of cold water, $50 \%$ or $95 \%(\mathrm{v} / \mathrm{v})$ ethanol by stirring for 2 $\mathrm{hr}$ at room temperature. After an overnight stand (about $18 \mathrm{hr}$ ) at room temperature, the samples were filtered using Whatman filter paper No. 1 (Sigma-Aldrich, Michigan, USA), and the residue was extracted with additional $200 \mathrm{~mL}$ of solvent as described previously. The combined extracts were evaporated under vacuum at $40^{\circ} \mathrm{C}$ using a rotary evaporator (BÜCHI 011 Rotavapor, Switzerland) to dryness (Reddy \& Mathew, 2001). For determination of antioxidant activities and analysis of antioxidant components, the dried extracts were weighed, re-dissolved in 100 ethanol (95\%) and stored at $4^{\circ} \mathrm{C}$ until used. As for the antibacterial testing, the dried extracts were re-dissolved at concentration of $0.5 \mathrm{~g}$ in $1 \mathrm{~mL}$ of dimethyl sulfoxide (DMSO) $(0.1 \%, \mathrm{v} / \mathrm{v}$ in sterile water). Extracts were stored at $-18^{\circ} \mathrm{C}$ until used.

\section{Determination of bioactive components}

The total polyphenol contents in the ethanolic (95\%) extracts were determined according to the Folin-ciocalteu method (Singleton \& Rossi, 1965). The concentration of total phenolic compounds was calculated based on standard curve of gallic acid $(0.01-0.05 \mathrm{mg} / \mathrm{mL})$ and the results were expressed as $\mathrm{mg}$ gallic acid equivalent (GAE)/g.

The total flavonoid contents in the ethanolic (95\%) extracts were determined using the aluminium chloride colorimetric assay (Zou et al., 2004). In brief, $100 \mu \mathrm{L}$ mushroom extract was mixed with $500 \mu \mathrm{L}$ distilled water and $30 \mu \mathrm{L} \mathrm{NaNO}_{2}$ solution $(5 \%)$. After $5 \mathrm{~min}, 60 \mu \mathrm{L} \mathrm{AlCl} 3 \cdot \mathrm{H}_{2} \mathrm{O}$ solution (10\%) was added. After 6 min, $200 \mu \mathrm{L} \mathrm{NaOH} \mathrm{(1}$ M) and $110 \mu \mathrm{L}$ distilled water were added to the mixture. The solution was mixed well, and the intensity of pink colour was measured at $510 \mathrm{~nm}$ using UV-vis Spectrophotometer. The total flavonoid concentration of each extract was calculated ,based on a standard curve of rutin $(0.1-1.0 \mathrm{mg} / \mathrm{mL})$, and was expressed as $\mathrm{mg}$ of rutin equivalents (RE) per g dry weight (dw) (Naegele, 2012). Ascorbic acid content in each mushroom sample was determined by titration with 2,6-dichlorophenol indophenol dye according to the AOAC (2010).

Crude fat was extracted using Soxhlet extraction method. Samples were saponified and vitamin E was extracted and determined according to the methods described by De Leenheer et al. (1988) and Podda et al. (1996). The extracted lipids (0.2 g) were saponified by adding $25 \mathrm{~mL}$ of $20 \%$ alcoholic potassium hydroxide and refluxing at $85{ }^{\circ} \mathrm{C}$ for $4 \mathrm{hr}$. The non saponified lipids were extracted twice with $50 \mathrm{~mL}$ of diethyl ether. The combined ether layer was collected and washed with water, and then dried over anhydrous sodium sulphate. The solvent was then evaporated to dryness and the residuals were resuspended in HPLC grade meth- 
anol and filtered with $0.2 \mu \mathrm{m}$ PTFE filter before analysis. $20 \mu \mathrm{L}$ were injected on top of the HPLC column Phenomenex, USA C18 $(100 \mathrm{~mm}$ x $4.6 \mathrm{~mm}$ i.d.) operated at $35^{\circ} \mathrm{C}$. Mobile phase consisting of acetonitrile: methanol $(70: 30)$ at a flow rate 0.7 $\mathrm{mL} / \mathrm{min}$ was used in isocratic elution mode. The separated compounds were detected using VWD at 205 nm.(Puttaraju et al., 2006)

\section{Identification and quantification of indi- vidual phenolic compounds}

To identify the phenolic compounds of mushroom extracts, HPLC 1260 Agilent Infinity (Agilent Technologies, Palo Alto, CA, USA) with a Variable Wavelength Detector (VWD) system was used according to Podda et al. (1996). Mushroom ethanolic $(95 \%)$ extracts $(10 \mu \mathrm{L})$ were injected into the HPLC system equipped with a reversed-phase column plusC18 (100 $\mathrm{mm}$ x $4.6 \mathrm{~mm}$ i.d.) operated at $30^{\circ} \mathrm{C}$. The mobile phase used was ternary elution gradient mode with the following conditions: (A) HPLC grade water $0.2 \% \mathrm{H}_{2} \mathrm{PO}_{4}$, (B) methanol, and $(\mathrm{C})$ acetonitrile. The flow rate was set at $0.4 \mathrm{~mL} / \mathrm{min}$, and the injection volume was $20 \mu \mathrm{L}$. Polyphenols were detected at $284 \mathrm{~nm}$ using a Variable Wavelength Detector (VWD). For separation of flavonoids, column plus C18 (150 mm x 4.6 $\mathrm{mm}$ i.d.) operated at $35^{\circ} \mathrm{C}$, mobile phase of HPLC grade water and $0.5 \% \mathrm{H}_{2} \mathrm{PO}_{4}(50: 50, \mathrm{v} / \mathrm{v})$ with flow rate of $0.7 \mathrm{~mL} / \mathrm{min}$ was used. The injection volume was $20 \mu \mathrm{L}$ and the separated compounds were detected using VWD at $273 \mathrm{~nm}$. Fourteen commercial phenolic compounds were used as standards (gallic, caffeic, catechol, $p$-hydroxy benzoic acid, caffeine, vanillic acid, syringic acid, vanillin, $p$ coumaric acid, benzoic acid, ferulic acid, ellagic, salicylic acid and cinnamic acid).

\section{Antioxidant activity}

\section{1,1-Diphenyl-2-picrylhydrazyl (DPPH) radical scavenging activity}

The DPPH scavenging activity was determined according to the modified method described by Brand-Williams et al (1995). Briefly, $0.25 \mathrm{~mL}$ of the ethanolic extracts (6.5 and $8.75 \mathrm{mg}$ for mushrooms cultivated on RS and RS+WS, respectively) were added to $2.75 \mathrm{~mL}$ of $0.1 \mathrm{mmol} \mathrm{DPPH}$ in methanol solution. The mixture was shaken vigorously and left to stand in the dark for $30 \mathrm{~min}$ at room temperature, and the absorbance was then measured at $517 \mathrm{~nm}$ against a blank using the UVvis Spectrophotometer (Pharmacia LKB, NOVA
Spec II). The radical scavenging activity was calculated as a percentage of DPPH discoloration using the equation:

Scavenging activity $(\%)=\left[\left(\mathrm{A}_{\text {Contro }}-\mathrm{A}_{\text {Sample }}\right) / \mathrm{A}_{\text {Control }}\right]$ $\times 100$

Where $\mathrm{A}_{\text {Sample }}$ is the absorbance of tested sample and $\mathrm{A}_{\text {Control }}$ is the absorbance of the control (DPPH solution). The $\mathrm{IC}_{50}$ value is defined as the total antioxidant necessary to decrease the initial DPPH radical concentration by $50 \%$. L-ascorbic acid was used as standard control. The results of the assay were expressed as mg ascorbic acid equivalents (AAE)/g DW.

\section{Ferric reducing power (FRP) assay}

The reducing power of the mushroom extracts was determined using ferric reducing power method of Oyaizu (1986). In brief, $1.0 \mathrm{~mL}$ of the ethanolic extracts (26 and $35 \mathrm{mg}$ for mushrooms cultivated on RS and RS+WS, respectively) were mixed with $2.5 \mathrm{~mL}$ of $1 \%$ potassium ferricyanide in $0.2 \mathrm{M}$ phosphate buffer ( $\mathrm{pH}$ 6.6), and the mixture was incubated at $50{ }^{\circ} \mathrm{C}$ for $20 \mathrm{~min}$., $2.5 \mathrm{~mL}$ of $10 \%$ trichloroacetic acid were added to the mixture, which was then centrifuged at $1036 \times \mathrm{g}$ for $10 \mathrm{~min}$. The upper layer of the solution $(2.5 \mathrm{~mL})$ was mixed with distilled water $(2.5 \mathrm{~mL})$ and freshly prepared $\mathrm{FeCl}_{3}$ solution $(0.5 \mathrm{~mL}, 0.1 \%)$. The absorbance of the solution was measured at $700 \mathrm{~nm}$ using the UV-vis Spectrophotometer. The standard (Potassium ferrocyanide) was also processed by the same procedure and the results were reported as mmol $\mathrm{K}_{4} \mathrm{Fe}(\mathrm{CN})_{6}$ equivalent/100 $\mathrm{g}$ dry weight.

\section{Hydroxyl radical-scavenging activity}

Hydroxyl radical scavenging activity of the 95\% ethanolic extracts was measured according to the method of Halliwell et al. (1987) with a slight modification (Barros et al., 2008). In brief, the assay was performed by adding, in sequence, $0.1 \mathrm{~mL}$ of EDTA $(1 \mathrm{mM}), 0.01 \mathrm{~mL}$ of $\mathrm{FeCl}_{3}(10 \mathrm{mM}), 0.1$ $\mathrm{mL}$ of $\mathrm{H}_{2} \mathrm{O}_{2}(10 \mathrm{mM}), 0.36 \mathrm{~mL}$ of deoxyribose (10 $\mathrm{mM}), 0.25 \mathrm{~mL}$ of the ethanolic extract ( 6.5 and 8.75 $\mathrm{mg}$ for mushrooms cultivated on RS and RS+WS, respectively) dissolved in $0.75 \mathrm{ml}$ distilled water, $0.33 \mathrm{~mL}$ of phosphate buffer $(50 \mathrm{mM}, \mathrm{pH} 7.4)$ and $0.1 \mathrm{~mL}$ of ascorbic acid $(1 \mathrm{mM})$. This mixture was then incubated at $37^{\circ} \mathrm{C}$ for $1 \mathrm{hr}$. A $1.0 \mathrm{~mL}$ portion of the incubated mixture was mixed with $1.0 \mathrm{~mL}$ of $10 \%$ TCA and $1.0 \mathrm{~mL}$ of $0.5 \%$ butylated hydroxyanisole (in $0.025 \mathrm{M} \mathrm{NaOH}$ containing $0.025 \%$ ) to develop a pink chromogen that was measured at 
$532 \mathrm{~nm}$ using the UV-Vis Spectrophotometer. The hydroxyl radical-scavenging activity of the extract was reported as \% inhibition of deoxyribose degradation and was calculated by the formula:

$\mathrm{OH}^{\prime}$-scavenged \% $=\left[\left(\mathrm{A}_{\text {control }}-\mathrm{A}_{\text {test }}\right) / \mathrm{A}_{\text {control }}\right] \times 100$.

Where $A_{\text {control }}$ is the absorbance of the control reaction and $A_{\text {test }}$ is the absorbance of the tested sample.

\section{Antibacterial activity}

Antibacterial activities of mushroom extracts were tested against two Gram negative (Escherichia coli ATCC 25922; Salmonella typhimurium ATCC 14028) and two Gram-positive (Staphylococcus aureus ATCC 6538 and Bacillus cereus isolate) bacteria. The $B$. cereus isolate was isolated from Ultra-Heat milk and identified using $16 \mathrm{~S}$ rRNA analysis. Staph. aureus and B. cereus were cultured on Baird parker agar and nutrient agar, respectively. Whereas, E. coli and S. typhimurium were both cultured on violet red bile lactose agar. The antimicrobial activity of mushroom extracts was assayed by 2 methods: agar-well diffusion assay (Magaldi et al., 2004) and standard broth dilution method (Clinical and Laboratory Standards Institute,2009). All experiments were performed in triplicate.

\section{Agar-well diffusion assay}

In brief, an inoculum containing $10^{8} \mathrm{CFU} / \mathrm{ml}$ of each of the bacterial cultures was added to an appropriate molten agar medium $(20 \mathrm{~mL})$ for each strain prior to its solidification, mixed and poured into a Petri dish. Then, $9 \mathrm{~mm}$ diameter wells were cut into the surface of the agar using the back of a sterile blue tip and $100 \mu \mathrm{L}$ of each extract at concentration of $500 \mathrm{mg} / \mathrm{mL}$ was added to each well. Plates were incubated for $24 \mathrm{hr}$ at $30^{\circ} \mathrm{C}$ for B. cereus and at $37^{\circ} \mathrm{C}$ for Staph. aureus, E. coli and $S$. typhimurium. Under the same conditions, tetracycline $(250 \mathrm{mg})$, clindamycin $(150 \mathrm{mg})$, levofloxacin $(250 \mathrm{mg})$, and Ampiflux (125 mg) were tested as the positive controls (standard antibiotics) for B. cereus, Staph. aureus, E. coli and S. typhimurium, respectively. The effect of dimethyl sulfoxide (DMSO) $(0.1 \%)$ as a negative control on the growth of each strain was also tested. Inhibition zones around discs indicated the presence of antimicrobial activity, which was measured using a measuring ruler. The average diameter of the inhibition zone was measured in millimeter, and the activities were classified according to the follow- ing scale: inhibition zones less than $9 \mathrm{~mm}$, inactive; 9-12 $\mathrm{mm}$, moderately active; $13-18 \mathrm{~mm}$, active; above $18 \mathrm{~mm}$, very active. Each assay was carried out in triplicate (Magaldi et al., 2004).

\section{Minimal inhibitory concentrations assay}

A serial of a 2-fold macro-broth dilution method was performed to determine the minimum inhibitory concentration (MIC) of mushroom extracts according to the standard method (Clinical and Laboratory Standards Institute, 2009). The stock solution of the tested extracts $(500 \mathrm{mg} / \mathrm{mL})$ were prepared, and 2-fold serial dilutions of extracts were performed. Concentrations of mushroom extracts ranged from 0.48 to $500 \mathrm{mg} / \mathrm{mL}$ were tested. To each test tube, $950 \mu \mathrm{L}$ of nutrient broth, $50 \mu \mathrm{L}$ of bacterial suspension $\left(10^{8} \mathrm{CFU} / \mathrm{mL}\right)$, and $1000 \mu \mathrm{L}$ of extract dilution were added. The positive controls contained $1950 \mu \mathrm{L}$ of nutrient broth and 50 $\mu \mathrm{L}$ of each inoculum without extracts. The tubes were incubated for $24 \mathrm{hr}$ at $30^{\circ} \mathrm{C}$ for $B$. cereus and $37^{\circ} \mathrm{C}$ for the other 3 strains. Bacterial growth was determined by measuring turbidity at $600 \mathrm{~nm}$ using UV-Vis Spectrophotometer. MIC value (expressed as $\mathrm{mg} / \mathrm{mL}$ ) was determined for each extract at the lowest concentration where no turbidity was observed. All samples were tested in triplicates.

\section{RESULTS AND DISCUSSION}

\section{Yield of mushroom extracts}

Cold water or ethanol of $50 \%$ and $95 \%$ concentration were used to extract the bioactive compounds from $P$. ostreatus cultivated on RS or RS+WS substrates. Table (1) shows the effect of substrate and extraction solvent on the yield. The extract yield of mushroom grown on RS+WS substrate was higher than those grown on RS substrate alone in all the tested solvents. The yield ranged from 13.0 to $17.5 \%$, from 28 to $49 \%$ and from 31 to $60 \%$ for samples extracted with $95 \%$ ethanol, $50 \%$ ethanol and cold water, respectively (Table 1). In addition, the extraction yield of bioactive compounds decreased with increasing the ethanol concentration (Table 1). The yield of aqueous extracts was relatively higher than those of alcoholic extracts due to the high content of water soluble (polar) constituents in mushroom, such as proteins, polysaccharides and mineral salts (Puttaraju et al., 2006). Moreover, Sudha et al. (2012)found that the extract yield of various mushrooms was relatively 
higher in water than alcohols (ethanol or methanol) due to the extraction of high amount of polysaccharides such as glucan and soluble proteins. Also, the alcoholic extracts were very rich in phenolics and flavonoids.

\section{Bioactive components in mushrooms}

Mushrooms have high levels of phenolic compounds, which are composed of one or more aromatic rings bearing one or more hydroxyl groups and comprise a large and diverse group of molecules, including flavonoids. Due to the presence of hydroxyl groups in phenolic compounds, they are more soluble in polar solvents such as methanol and ethanol as well as their aqueous mixtures. Because ethanol (95\%) is not toxic, it was used for the extraction and assessment of total phenols (TP) and flavonoid (TF) contents, which were expressed as $\mathrm{mg}$ gallic acid (GAE/g DW) and rutin (RE/g DW) equivalents per gram of sample dry weight, respectively (Table 2). Mushroom grown on RS+WS contained higher amounts of total phenolic contents (TPC) and total flavonoid contents (TFC) than those grown on RS alone (Table 2). The TPC were $1.30 \pm 0.05$ and $1.78 \pm 0.09 \mathrm{mg}$ GAE $/ \mathrm{g}$ DW for grown mushrooms on RS and RS+WS, respectively. These results are slightly similar to those reported previously, and ranged from 0.93 to $1.42 \mathrm{mg}$ GAE/g DW based on the extraction solvent and species (Karaman et al., 2010, Oke \& Aslim, 2011). Higher TFC (2.53 and $2.83 \mathrm{mg}$ $\mathrm{RE} / \mathrm{g} \mathrm{DW}$ ) were measured in mushroom grown on $\mathrm{RS}$ and RS+WS, respectively (Table 2), which are close to those reported (1.2 to $2.9 \mu \mathrm{g} / \mathrm{g}$ ) from different species of Pleurotus extract (Vieira et al., 2013). The amounts of TPC and TFC in mushroom can vary with species, cultivation methods, substrates, drying methods, aging, extraction solvents and temperature(Choi et al., 2006, Gąsecka et al., 2016).

Ascorbic acid (vitamin C) is reported to interact directly with radicals such as hydrogen peroxide, peroxyl radicals, singlet oxygen, superoxide and hydroxyl radical, which prevents free radical damage. It also assists $\alpha$-tocopherol in the inhibition of lipid peroxidation by recycling the tocopherol radical (Beyer, 1992). Relatively high concentrations of vitamin $\mathrm{C}$ (6.3 and $5.2 \mathrm{mg} / 100 \mathrm{~g} \mathrm{DW})$ were found in the cultivated mushroom on RS and RS+WS, respectively. In general, there are contradictory results about $P$. ostreatus content of vitamin $C$ that ranges from 0 (not detected) to 20 (high) mg/100g DW (Mattila et al., 2001). Previous reports indicated that vitamin $\mathrm{C}$ content in mushroom varies depending on species, age, climate, storage, drying and handling (Tsai et al., 2006).Importantly, significantly high amount of $\alpha$-tocopherol (1.1 and $27.9 \mathrm{mg} / 100 \mathrm{~g}$ DW) was detected in the mushroom grown on RS-WS compared to that grown on RS alone.

Elattar et al. (2019) showed that mushroom cultivated on RS-WS was higher in its fat content compared with that grown on RS. The $\alpha$-tocopherol is a fat soluble vitamin, thereby its concentration depends on the fat content in mushroom sample. Fresh $P$. ostreatus mushroom contained 40.46$55.16 \mathrm{mg} / 100 \mathrm{gm}$ total tocopherols (Jaworska et al., 2015). While, Jayakumar et al. (2009) reported the presence of $\alpha$-tocopherol in an amount of 30.1 $\mathrm{mg} / 100 \mathrm{~g}$ dry weight. The $\alpha$-tocopherol is the most biologically active form of vitamin $\mathrm{E}$, and capable of protecting human from degenerative diseases like cardiovascular diseases or cancer. It prevents lipid peroxidation due to its high antioxidant activity and ability to deactivate the reactive oxygen species. Together, these results suggest that the mushroom grown on agro-waste such as RS and its supplement with WS (1:1) are good sources of several bioactives compounds such as polyphenols, flavonoids and vitamins (Table 2).

Table 1: Effect of different substrates and solvents on yield of $\boldsymbol{P}$. ostreatus extracts

\begin{tabular}{lll}
\hline \multirow{2}{*}{ Solvent } & \multicolumn{2}{c}{ Extraction Yield (\%, w/w) } \\
\cline { 2 - 3 } & \multicolumn{1}{c}{ RS } & RS+WS \\
\hline 95\% ethanol & $13 \pm 0.03$ & $17.5 \pm 0.07$ \\
$50 \%$ ethanol & $28 \pm 0.05$ & $49 \pm 0.02$ \\
Cold water & $31 \pm 0.06$ & $60 \pm 0.06$ \\
\hline
\end{tabular}

Values represent the mean \pm standard error of 3 replicates. RS and RS+WS, P. ostreatus was cultivated on rice straw and a mixed rice and wheat straws $(1: 1, \mathrm{w} / \mathrm{w})$ substrates, respectively.

\section{Phenolic profiles}

Polyphenols are the major antioxidant components that were reported in extracts of several mushroom species including $P$. ostreatus (Gąsecka et al., 2016).Fourteen standard phenolic compounds were used for identification of phenolics, among which the phenolic acids and flavonoids were identified in ethanolic extracts of both cultivated mushrooms on RS and RS+WS substrate using HPLC analy- 
Table 2: Bioactive compounds contents of $\boldsymbol{P}$. ostreatus cultivated on agro-wastes.

\begin{tabular}{ccccc}
\hline Mushroom sample & $\begin{array}{c}\text { Total Phenols } \\
(\mathrm{mg} \mathrm{GAE} / \mathrm{g})\end{array}$ & $\begin{array}{c}\text { Total flavonoid } \\
(\mathrm{mg} \mathrm{RE} / \mathrm{g})\end{array}$ & $\begin{array}{c}\text { Ascorbic acid } \\
(\mathrm{mg} / 100 \mathrm{~g})\end{array}$ & $\begin{array}{c}\alpha \text {-tocopherol } \\
(\mathrm{mg} / 100 \mathrm{~g})\end{array}$ \\
\hline RS & $1.30 \pm 0.05$ & $2.53 \pm 0.07$ & $6.3 \pm 0.0$ & 1.1 \\
RS+WS & $1.78 \pm 0.09$ & $2.83 \pm 0.02$ & $5.2 \pm 0.0$ & 27.9 \\
\hline
\end{tabular}

Values represent the mean \pm standard error of 3 replicates. RS and RS + WS, P. ostreatus was cultivated on rice straw or mixed rice and wheat straws $(1: 1, \mathrm{w} / \mathrm{w})$ substrates, respectively. ${ }^{*} \mathrm{GAE}$, gallic acid equivalent. RE, rutin equivalent.

sis (Table 3). Nine phenolic compounds including, naringenin (68.7 and $56.6 \mu \mathrm{g} / \mathrm{g} \mathrm{DW})$, apigenin (39.8 and $16.9 \mu \mathrm{g} / \mathrm{g} \mathrm{DW}$ ), $p$-hydroxy benzoic acid (15.3 and $9.4 \mu \mathrm{g} / \mathrm{g}$ DW), kaempferol (11.3 and 6.5 $\mu \mathrm{g} / \mathrm{g} \mathrm{DW}$ ) and quercetin (6.4 and $5.4 \mu \mathrm{g} / \mathrm{g} \mathrm{DW}$ ) as the major compounds, in addition to, caffeic acid, cinnamic acid, gallic acid and $o$-coumaric acid were detected in both of the ethanolic extracts (Table 3). On the other hand, ellagic acid was only detected in mushroom grown on RS, while $p$-coumaric acid was detected in mushroom grown on RS+WS (Table 3). Low amounts of gallic acid were detected in both of the extracts of cultivated mushrooms (2.1 and $0.5 \mu \mathrm{g} / \mathrm{g} \mathrm{DW}$ ) (Table 3). Similarly, low amount of gallic acid was reported ( 7 and $13 \mu \mathrm{g} / \mathrm{g} \mathrm{DW}$ ) by Palacios et al. (2011). The $p$-Hydroxy benzoic acid was the most abundant phenolic acid in both of the cultivated mushroom. Previously, $p$-coumaric acid was only identified in $P$. ostreatus at 11.15 and $76.91 \mu \mathrm{g} / \mathrm{g}$ DW (Gąsecka et al., 2016). High amounts of naringenin, a flavonoid, was found in a range of 56.6 and $68.7 \mu \mathrm{g} / \mathrm{g}$ DW in both of the cultivated mushrooms (Table 3). Previous studies showed a very low level of naringenin that ranged

Table 3: Phenolic acid and flavonoid composition of the ethanolic extracts of oyster mushrooms cultivated on agro-wastes.

\begin{tabular}{|c|c|c|c|c|}
\hline \multirow[t]{2}{*}{ Compound } & \multicolumn{2}{|c|}{$\begin{array}{c}\text { Concentration } \\
(\mu g / G)\end{array}$} & \multirow[t]{2}{*}{ Activity } & \multirow[t]{2}{*}{ References } \\
\hline & $\mathbf{R S}$ & $\mathbf{R S}+\mathbf{W S}$ & & \\
\hline \multicolumn{5}{|l|}{ Phenolic acid } \\
\hline Caffeic acid & 0.8 & 0.6 & antibacterial\&antioxidant & Liu et al., 2014 \\
\hline Cinnamic acid & 0.7 & 0.4 & antimicrobial & Liao et al., 2012 \\
\hline Ellagic acid & 0.6 & 0.0 & $\begin{array}{l}\text { antimicrobial \& } \\
\text { anti-biofilm formation }\end{array}$ & $\begin{array}{l}\text { De et al., } 2018 \text { and } \\
\text { Fontaine et al., } 2017\end{array}$ \\
\hline Gallic acid & 2.1 & 0.5 & bacteriostatic \& antioxidant & Kim, 2007 \\
\hline$o$-Coumaric acid & 0.9 & 0.3 & radical scavenging & Velkov et al., 2007 \\
\hline$p$-Coumaric acid & 0.0 & 0.2 & $\begin{array}{l}\text { antioxidant \& } \\
\text { antimicrobial }\end{array}$ & $\begin{array}{l}\text { Ekinci-Akdemir et al., } 2017 \text { and Lou } \\
\text { et al., } 2012\end{array}$ \\
\hline $\begin{array}{l}p \text {-Hydroxy benzoic } \\
\text { acid }\end{array}$ & 15.3 & 9.4 & $\begin{array}{l}\text { LDL oxidation inhibitor, } \\
\text { Antifungal \&antimicrobial }\end{array}$ & $\begin{array}{l}\text { Chong et al., 2009; Heleno et al., } \\
2013 \text { and Hur et al., } 2003\end{array}$ \\
\hline \multicolumn{5}{|l|}{ Flavonoids } \\
\hline Apigenin & 39.8 & 16.9 & anti-fungal & $\begin{array}{l}\text { Cushnie and Lamb, } 2005 \text { and Leopol- } \\
\text { dini et al., } 2004\end{array}$ \\
\hline Kaempferol & 11.3 & 6.5 & antioxidant & $\begin{array}{l}\text { Calderon-Montano et al., 2011; Park } \\
\text { et al., } 2006 \text { and Zeng et al., } 2019\end{array}$ \\
\hline Naringenin & 68.7 & 56.6 & $\begin{array}{l}\text { antibacterial \& } \\
\text { antioxidative }\end{array}$ & $\begin{array}{l}\text { Sajitha Lulu et al., } 2016 \text { and Cavia } \square \\
\text { Saiz et al., } 2010\end{array}$ \\
\hline Quercetin & 6.4 & 5.4 & $\begin{array}{l}\text { antioxidant \& } \\
\text { anti-biofilms }\end{array}$ & $\begin{array}{l}\text { Bu et al., 2011; Ouyang et al., 2016; } \\
\text { Sajitha Lulu et al., 2016; Velkov et } \\
\text { al., } 2007 \text { and Zeng et al., } 2019\end{array}$ \\
\hline
\end{tabular}

RS and RS+WS, $P$. ostreatus was cultivated on rice straw or mixed rice and wheat straws $(1: 1, \mathrm{w} / \mathrm{w})$ substrates, respectively. 
from $0.15 \pm 0.03$ to $10 \mu \mathrm{g} / \mathrm{g}$ DW (Yen et al., 1993, Naczk \& Shahidi, 2004). Other flavonoids were also detected in large amounts such as apigenin (39.8 and $16.9 \mu \mathrm{g} / \mathrm{g} \mathrm{DW}$ ), quercetin (6.4 and 5.4 $\mu \mathrm{g} / \mathrm{g}$ DW) in the mushroom (Table 3).

\section{Antioxidant activity}

The antioxidant activity of various mushroom extracts may be due to the reduction of hydroperoxide, inactivation of free radicals, binding with metal ions, presence of phytochemicals (i.e. phenolic compounds), or a combination of these possibilities (Choi et al., 2005).Many studies have shown a high correlation between antioxidative activities and phenolic content (Fernandez-Panchon et al., 2008). Phenolic compounds display extensive free radical-scavenging activities as hydrogen donors, electron-donating agents (reducing agents), and metal ion chelating properties. Therefore, the antioxidant activity of the $95 \%$ ethanolic extracts of both cultivated mushrooms was evaluated by three different methods; namely, DPPH free radical scavenging, ferric reducing power (FRP) and hydroxyl scavenging activity assays, the results are shown in Table (4).

Scavenging of DPPH free radicals is a widely used method to evaluate antioxidant activity of specific compounds or extracts in a relatively short time compared with other methods. The DPPH is a stable, free radical that accepts an electron or hydrogen radical producing a purple colour in alcohols but becomes pale when it reacts with antioxidant molecules (Chorvathova et al., 1993). The scavenging effects of the ethanolic extracts of cultivated mushrooms on DPPH radical are shown in Table (4).
For both mushrooms grown on RS and RS+WS, the scavenging effect on DPPH radicals increased with increasing the concentration of mushroom extract (not shown here). The ethanolic extracts of $P$. ostreatus grown on RS+WS had a slightly higher scavenging ability $(51.40 \%$; inhibition \%) than that grown on RS (50.87\%) (Table 4). These activities imply the presence of antioxidant components that can react rapidly with DPPH radicals. The $\mathrm{IC}_{50}$ values were found to be 48.39 (RS) and 47.62 (RS+WS) $\mathrm{mg} / \mathrm{ml}$ for $50 \%$ inhibition of DPPH free radicals (Table 4). These results are in agreement with several studies, which detected a potent antioxidant activity against DPPH radical in ethanolic extracts of Pleurotus spp.(FernandezPanchon et al., 2008).

The efficacy of certain antioxidants is known to be associated with their reducing power. Therefore, transformation of $\mathrm{Fe}^{3+}$ to $\mathrm{Fe}^{2+}$ was measured according to the method of Oyaizu (1986).Ethanolic extracts from mushrooms samples grown on RS+WS showed a higher reducing power (316.90 mmol $\mathrm{K}_{4} \mathrm{Fe}(\mathrm{CN})_{6}$ equivalent $\left./ 100 \mathrm{~g} \mathrm{DW}\right)$ than that grown on RS (193.66 $\mathrm{mmol} \mathrm{K}_{4} \mathrm{Fe}(\mathrm{CN})_{6}$ equivalent/100 g DW) as shown in Table (4). Thus, this result indicated the presence of reductone, which could react with free radicals to stabilize and block radical chain reactions.

The hydroxyl radical is the most reactive oxygen species that can induce oxidative damage to DNA, lipids and proteins (Choi et al., 2006). For RS and RS+WS cultivated mushrooms extracts, the hydroxyl radical-scavenging effects were 40.74 and $45.50 \%$, respectively (Table 4 ). These results together indicate that the cultivated mushrooms on RS and RS+WS substrates contain significant

Table 4: Antioxidant activity of $\boldsymbol{P}$. ostreatus cultivated on agro-wastes.

\begin{tabular}{lcc}
\hline Assay & RS & RS+WS \\
\hline DPPH scavenging assay & & $51.40 \pm 2.0$ \\
$\quad$ Scavenging activity (\%) & $50.87 \pm 1.0$ & $1.58 \pm 0.03$ \\
Ascorbic acid equivalent $(\mathrm{mg} / \mathrm{g})$ & $1.55 \pm 0.03$ & $47.62 \pm 1.8$ \\
$\mathrm{IC}_{50}(\mathrm{mg} / \mathrm{ml})$ & $48.39 \pm 0.9$ & $316.90 \pm 3.6$ \\
FRAP* assay & & \\
mmol K & & \\
$\mathrm{OH}^{\prime}$-scavenging activity & $193.66 \pm 3.6$ & $45.50 \pm 0.7$ \\
$\quad \mathrm{OH}^{\prime}$-scavenged (\%) & & $40.74 \pm 0.5$ \\
\hline
\end{tabular}

Values represent the mean \pm standard error of 3 replicates. RS and RS+WS, P. ostreatus was cultivated on rice straw or mixed rice and wheat straws $(1: 1, \mathrm{w} / \mathrm{w})$ substrates, respectively. ${ }^{*} \mathrm{FRAP}=$ ferric reducing antioxidant power. 
amounts of antioxidant compounds such as polyphenols and flavonoids, which are rich in the alcoholic extract of mushrooms (Venkatakrishnan et al., 2010).In addition, their alcoholic extracts can be used as food additives with a free radical inhibitor or scavenger activity for inactivating free radicals. The greater numbers of hydroxyl groups in the phenolics may result in higher antioxidant activity(Fernandez-Panchon et al., 2008). Natural phenolics are able to provide antioxidative function through intercepting singlet oxygen, decomposing primary products of oxidation, preventing continued hydrogen abstraction from substances, etc. (Gunde-Cimerman, 1999).

\section{Antibacterial activity of mushrooms extracts}

Many studies have reported that mushrooms are potential sources for antimicrobial against different classes of pathogens including pathogenic bacteria, fungi and virus (Masri et al., 2017). Most of the identified 70 species of Pleurotus spp. have medicinal effects such as antimicrobial properties.

The prepared extracts were evaluated for potential antimicrobial activity against four foodborne bacterial pathogens using two methods (agar-well diffusion and macro-broth dilution methods). The antimicrobial activity of the water and ethanolic (50 and $95 \%$ ) extracts of mushroom cultivated on RS and RS+WS substrates were tested using the agarwell diffusion plate and expressed as zone of inhibi- tion $(\mathrm{mm} \pm \mathrm{SD})$. Preliminary results showed that a very weak antibacterial activity was obtained when 95\% ethanolic extracts were tested (not shown). Ethanolic extract $(50 \%)$ exhibited high antibacterial activity against Gram-negative bacteria and caused inhibition halo ranging from 16 to $23 \mathrm{~mm}$ for the Salmonella typhimurium $(19.5 \pm 0.7 \mathrm{~mm})$ and the highest for $E$. coli $(23.25 \pm 1.8 \mathrm{~mm})$ strains (Table 5). While, the mean inhibition zone of growth was $(16.75 \pm 0.35)$ against the tested Gram-positive bacteria (Staph aureus) (Table 5).The lowest antibacterial activities were obtained with ethanol RS extracts, which produced $11.5 \pm 0.7 \mathrm{~mm}$ zone of inhibition against Staph aureus (Table 4). On the other hands, the aqueous extract of mushroom cultivated on RS showed the lowest activity against $S$. typhimurium ( $12 \pm 0.0 \mathrm{~mm}$, inhibition zone diameter). However, all mushroom extracts showed no inhibition against the Gram-positive bacteria $B$. cereus (Table 5). Importantly, extracts of mushroom cultivated on $\mathrm{RS}+\mathrm{WS}$ had more inhibition zone diameter against $E$. coli than when using levofloxacin as a standard drug. The aqueous extracts of mushrooms showed higher activity than hot water extracts (data not shown here), which agrees with previous works (Akyuz \& Kirbag, 2009). Furthermore, Venturini et al.(2008) reported that the methanol extract of $P$. ostreatus possessed antimicrobial activity only against Clostridium perfringens (Gram-positive bacteria) and not against other tested pathogenic bacterial strains including $B$. Cereus.

Table 5: Antimicrobial activity of mushrooms extracts against selected Gram-negative and Grampositive pathogenic bacteria

\begin{tabular}{|c|c|c|c|c|c|}
\hline \multirow{2}{*}{ Tested bacteria } & \multicolumn{2}{|c|}{ RS extracts } & \multicolumn{2}{|c|}{ RS+WS extracts } & \multirow{2}{*}{$\begin{array}{l}\text { Standard } \\
\text { Drugs* }\end{array}$} \\
\hline & Ethanol & Water & Ethanol & Water & \\
\hline \multicolumn{6}{|c|}{ Gram-negative bacteria } \\
\hline S. typhimurium & $18.5 \pm 0.7$ & $12 \pm 0.0$ & $19.5 \pm 0.7$ & $15.5 \pm 0.7$ & $30 \pm 0.0$ \\
\hline E. coli & $18.5 \pm 0.7$ & $15.5 \pm 0.7$ & $23.25 \pm 1.8$ & $18.5 \pm 0.7$ & $16 \pm 0.0$ \\
\hline \multicolumn{6}{|c|}{ Gram-positive bacteria } \\
\hline Staph. aureus & $11.5 \pm 0.7$ & $15.5 \pm 0.7$ & $16.75 \pm 0.35$ & $17.75 \pm 0.4$ & $54 \pm 0.0$ \\
\hline B. cereus & N.D. & N.D. & N.D. & N.D. & $29 \pm 0.0$ \\
\hline
\end{tabular}

Antimicrobial activity was determined in the extracts using agar-well diffusion and expressed as zone of inhibition in $\mathrm{mm} \pm \mathrm{SD}$. RS and RS+WS, $P$. ostreatus was cultivated on rice straw or mixed rice and wheat straws $(1: 1, \mathrm{w} / \mathrm{w})$ substrates, respectively. N.D., Not detected. * standard drugs $(250$ $\mathrm{mg} / \mathrm{mL}$ ) are listed in Materials and Methods. The mean zone of inhibition was determined from three independent results $(\mathrm{n})=3$.

\section{Minimal inhibitory concentrations}

The antibacterial activity of extracts of mushroom cultivated on RS+WS against E. coli, Staph. aureus and $S$. typhimurium were slightly higher 
than those cultivated on RS. Aqueous extract of mushroom cultivated on RS showed high antibacterial activity against $S$. aureus with minimal inhibitory concentrations (MIC) value of $125 \mathrm{mg} / \mathrm{mL}$, while ethanol extract of cultivated mushroom on RS did not show any antibacterial activity against Staph. aureus and B. cereus (Table 6). These results indicated that both aqueous and ethanolic extracts exhibit different antimicrobial activities against Gram-positive and Gram-negative bacteria. These differences in their antimicrobial activities might be due to a variation in the tested pathogenic strain, extraction solvent and the extracted antimicrobial components in each extract (Akyuz \& Kirbag, 2009, Manjunathan \& Kaviyarasan, 2010). These variations may also be due to the highly diversified groups of bioactive compounds present in mushrooms and also their high content of proteins that exhibit antibacterial activity(Younis et $a l ., 2015)$. For example, methanol and ethanol extracts of two strains of $P$. ostreatus (EVFB1 and EVFB4) showed weak antibacterial activity against both Gram-positive (Bacillus cereus CMGB 215) and Gram-negative (Escherichia coli $\mathrm{CBAB}$ 2, and Listeria innocua CMGB 218) bacterial strains (Va- manu et al., 2011). However, other research showed $P$. ostreatus extract to have high antimicrobial activities against Gram-positive (Staphylococcus aureus) and Gram-negative (E. coli) bacteria due to the presence of 3-(2-aminophenylthio)-3-hydroxypropanoic acid, which was identified as the antibacterial active compound (Younis et al., 2015).

Certain phenolic compounds were reported to be associated with antioxidant activity such as radical scavenging activity (Velkov et al., 2007; ,Vaz et al., 2011). As shown in Table (3), both extracts contain polyphenols and flavonoids components that exhibit not only antioxidant activity but also antimicrobial activity (e.g., gallic acid, caffeic acid, $p$-coumaric acid and quercetin). Therefore, the antioxidants and antibacterial activities of both extracts are linked to the activity of individual phenolic and flavonoids compounds. Extracts of mushroom cultured on RS+WS presented higher antimicrobial activity due to their high contents of TPC, TFC and $\alpha$-tocopherol. These results thus suggest that the aqueous and ethanolic extracts of both cultivated mushrooms on agro-waste can be utilized as natural antimicrobials.

Table 6. Minimum inhibitory concentrations $(\mathrm{mg} / \mathrm{mL})$ of mushrooms extracts against selected Gram negative and Gram-positive pathogenic bacteria.

\begin{tabular}{lcccc}
\hline \multirow{2}{*}{ Tested bacteria } & \multicolumn{2}{c}{ RS extracts } & \multicolumn{2}{c}{ RS+WS extracts } \\
\cline { 2 - 5 } & Ethanol 50\% & Water & Ethanol 50\% & Water \\
\hline Gram-negative bacteria & & & & \\
S. Typhimurium & 31.25 & N.D. & 15.625 & 31.25 \\
$\begin{array}{l}\text { E. coli } \\
\text { Gram-positive bacteria }\end{array}$ & 15.625 & 62.5 & 7.81 & 15.625 \\
Staph. aureus & & & & \\
B. cereus & N.D. & 125 & 31.25 & 15.625 \\
\hline
\end{tabular}

Antimicrobial activity was determined in the extracts using a serial two-fold macro-broth dilution method and expressed as MIC and was determined from three independent results $(\mathrm{n})=3$. RS and RS+WS, $P$. ostreatus was cultivated on rice straw or mixed rice and wheat straws $(1: 1, \mathrm{w} / \mathrm{w})$ substrates, respectively. Extracts were added at from stock solutions $(500 \mathrm{mg} / \mathrm{mL})$, and then two-fold serial dilutions of extracts were performed. N.D., Not detected. All extracts were found to be ineffective in inhibition of B. cereus growth up to $500 \mathrm{mg} / \mathrm{mL}$.

\section{CONCLUSION}

The $P$. ostreatus cultivation is an effective bioconversion process that is capable of transfering agro-wastes, such as rice and wheat straws, into potentially valuable bioactive extracts with great potential as natural antioxidant and antimicrobial additives for improving the shelf-life of food products during storage by preventing proteins and lipids oxidation as well as microbial growth. 


\section{ACKNOWLEDGMENTS}

The authors gratefully thankful to Prof. Dr. Ahmed Rafik El-Mahdy (Alexandria University) and Dr. Tarek Awad (University of Toronto) for fruitful discussions, and to Dr. Tarek Awad and Miss Alaa Awad (University of Toronto) for critically proof reading the manuscript. This study is a part of project entitled: Vigorous mushroom fermented milk summit proceeding. Funded by the Academy of Scientific Research and Technology, Egypt. Project ID 22.

\section{REFERENCES}

Akyuz, M. \& Kirbag, S. 2009. Antimicrobial activity of Pleurotus eryngii var. ferulae grown on various agro-wastes. EurAsian Journal of BioSciences, 3: 58-63.

AOAC 2010. Official Methods of Analysis, $18^{\text {th }}$ edn. Association of Official Analytical Chemists, Washington D. C., USA.

Barros, L., Falcão, S., Baptista, P., Freire, C., VilasBoas, M. \& Ferreira, I.C. 2008. Antioxidant activity of Agaricus sp. mushrooms by chemical, biochemical and electrochemical assays. Food Chemistry, 111: 61-66.

Beyer, R.E. 1992. An analysis of the role of coenzyme Q in free radical generation and as an antioxidant. Biochemistry and Cell Biology, 70: $390-403$.

Brand-Williams, W., Cuvelier, M.-E. \& Berset, C. 1995. Use of a free radical method to evaluate antioxidant activity. LWT-Food Sciences and Technology, 28: 25-30.

Bu, T., Mi, Y., Zeng, W. \& Zhang, C. 2011. Protective effect of quercetin on cadmium $\square$ induced oxidative toxicity on germ cells in male mice. Anat. Rec.: Advances in Integrative Anatomy and Evolutionary Biology, 294: 520-526.

Calderon-Montano, M., Burgos-Morón, E., PérezGuerrero, C. \& López-Lázaro, M. 2011. A review on the dietary flavonoid kaempferol. Mini-Reviews in Medicinal Chemistry, 11:298-344.

Cavia-Saiz, M., Busto, M.D., Pilar-Izquierdo, M.C., Ortega, N., Perez-Mateos, M. \& Muñiz, P. 2010. Antioxidant properties, radical scavenging activity and biomolecule protection capacity of flavonoid naringenin and its glycoside naringin: a comparative study. Journal of the Sciences of Food and Agriculture, 90: 1238-1244.

Chang, R. 1996. Functional properties of edible mushrooms. Nutrition Reviews, 54, S91-93.

Choi, Y., Lee, S., Chun, J., Lee, H. \& Lee, J. 2006. Influence of heat treatment on the antioxidant activities and polyphenolic compounds of Shiitake (Lentinus edodes) mushroom. Food Chemistry, 99: 381-387.

Choi, Y.M., Ku, J.B., Chang, H.B. \& Lee, J. 2005. Antioxidant activities and total phenolics of ethanol extracts from several edible mushrooms produced in Korea. Food Sciences Nutrition, 14: 700-703.

Chong, K.P., Rossall, S. \& Atong, M. 2009. In vitro antimicrobial activity and fungitoxicity of syringic acid, caffeic acid and 4-hydroxybenzoic acid against Ganoderma boninense. Journal Agriculture Sciences, 1: 15.

Chorvathova, V., Bobek, P., Ginter, E. \& Klvanova, J. 1993. Effect of the oyster fungus on glycaemia and cholesterolaemia in rats with insulin-dependent diabetes. Physiology Research, 42: 175-175.

Clinical and Laboratory Standards Institute. 2009. Performance standards for antimicrobial disk and dilution susceptibility tests for bacteria isolated from animals: approved standard: Nineteenth Informational Supplement M100S19. CLSI, Wayne, PA, USA.

Cushnie, T.T. \& Lamb, A.J. 2005. Antimicrobial activity of flavonoids. International Journal of Antimicrobial Agents, 26: 343-356.

De Leenheer, A.P., Nelis, H.J., Lambert, W.E. \& Bauwens, R.M. 1988. Chromatography of fat-soluble vitamins in clinical chemistry. Journal of Chromatography B: Biomedical Sciences and Applications, 429: 3-58.

De, R., Sarkar, A., Ghosh, P., Ganguly, M., Karmakar, B.C., Saha, D.R., Halder, A., Chowdhury, A. \& Mukhopadhyay, A.K. 2018. Antimicrobial activity of ellagic acid against Helicobacter pylori isolates from India and during infections in mice. Journal of Antimicrobial Chemotherapy, 73: 1595-1603.

Ekinci-Akdemir, F., Gülçin, I., Gürsul, C., Alwasel, S. \& Bayir, Y. 2017. Effect of p-coumaric acid against oxidative stress induced by cisplatin in brain tissue of rats. Journal of Applied Pharmaceutical Science, 27:1560-1564. 
Elattar, A., Hassan, S.M. \& Sh, A. 2019. Evaluation of Oyster Mushroom (Pleurotus ostreatus) Cultivation Using Different Organic Substrates. Alexandria Science Exchange Journal, 40: 427-440.

Elfeki, M., Elbestawy, E. \& Tkadlec, E. 2017. Bioconversion of Egypt's Agricultural Wastes into Biogas and Compost.Polish Journal of Environmental Studies, 26:1-10.

Fernandez-Panchon, M., Villano, D., Troncoso, A. \& Garcia-Parrilla, M. 2008. Antioxidant activity of phenolic compounds: from in vitro results to in vivo evidence. Critical Reviews in Food Science and Nutrition, 48: 649-671.

Fontaine, B.M., Nelson, K., Lyles, J.T., Jariwala, P.B., García-Rodriguez, J.M., Quave, C.L. \& Weinert, E.E. 2017. Identification of ellagic acid rhamnoside as a bioactive component of a complex botanical extract with anti-biofilm activity. Frontiers in Microbiology, 8: 496.

Frei, B. \& Higdon, J.V. 2003. Antioxidant activity of tea polyphenols in vivo: evidence from animal studies. The Journal of nutrition, 133: 3275S-3284S.

Gąsecka, M., Mleczek, M., Siwulski, M. \& Niedzielski, P. 2016. Phenolic composition and antioxidant properties of Pleurotus ostreatus and Pleurotus eryngii enriched with selenium and zinc. European Food Research and Technology, 242: 723-732.

Gunde-Cimerman, N. 1999. Medicinal value of the genus Pleurotus (Fr.) P. Karst.(agaricales sl, Basidiomycetes). International Journal of Medicinal Mushrooms, 1: 60-80.

Halliwell, B., Gutteridge, J. M. C., \& Arnoma, O. L. 1987. The deoxyribose method: A simple test tube assay for the determination of rate constant for reaction of hydroxyl radical. Analytical Biochemistry, 165: 215-219.

Heleno, S.A., Ferreira, I.C., Esteves, A.P., Ćirić, A., Glamočlija, J., Martins, A., Soković, M. \& Queiroz, M.J.R. 2013. Antimicrobial and demelanizing activity of Ganoderma lucidum extract, p-hydroxybenzoic and cinnamic acids and their synthetic acetylated glucuronide methyl esters. Food Chemistry Toxicology, 58: 95-100.

Hur, J.M., Park, J.G., Yang, K.H., Park, J.C., Park, J.R., Chun, S.S., Choi, J.S. \& Choi, J.W. 2003. Effect of methanol extract of Zanthox- ylum piperitum leaves and of its compound, protocatechuic acid, on hepatic drug metabolizing enzymes and lipid peroxidation in rats. Bioscience, Biotechnology, and Biochemistry, 67: 945-950.

Iwalokun, B., Usen, U., Otunba, A. \& Olukoya, D. 2007. Comparative phytochemical evaluation, antimicrobial and antioxidant properties of Pleurotus ostreatus. African Journal of Biotechnology, 6:1732-1739.

Jaworska, G., Pogoń, K., Bernaś, E. \& Duda $\square$ Chodak, A. 2015. Nutraceuticals and antioxidant activity of prepared for consumption commercial mushrooms Agaricus bisporus and Pleurotus ostreatus. Journal of Food Quality, 38: 111-122.

Jayakumar, T., Thomas, P. \& Geraldine, P. 2009. In-vitro antioxidant activities of an ethanolic extract of the oyster mushroom, Pleurotus ostreatus. Innovative Food Science and Emerging Technologies, 10: 228-234.

Karaman, M., Jovin, E., Malbaša, R., Matavuly, M. \& Popović, M. 2010. Medicinal and edible lignicolous fungi as natural sources of antioxidative and antibacterial agents. Phytotherapy Research, 24: 1473-1481.

Kim, Y.-J. 2007. Antimelanogenic and antioxidant properties of gallic acid. Biological and Pharmaceutical Bulletin, 30: 1052-1055.

Koutrotsios, G., Kalogeropoulos, N., Kaliora, A.C. \& Zervakis, G.I. 2018. Toward an increased functionality in Oyster (Pleurotus) mushrooms produced on grape marc or olive mill wastes serving as sources of bioactive compounds. Journal of Agriculture and Food Chemistry, 66: 5971-5983.

Leopoldini, M., Pitarch, I.P., Russo, N. \& Toscano, M. 2004. Structure, conformation, and electronic properties of apigenin, luteolin, and taxifolin antioxidants. A first principle theoretical study. Journal of Physical Chemistry A, 108: 92-96.

Liao, J.-C., Deng, J.-S., Chiu, C.-S., Hou, W.-C., Huang, S.-S., Shie, P.-H. \& Huang, G.-J. 2012. Anti-inflammatory activities of Cinnamomum cassia constituents in vitro and in vivo. Evidence-Based Complementary and Alternative Medicine, 2012: 429320.

Liu, M., Song, S., Li, H., Jiang, X., Yin, P., Wan, C., Liu, X., Liu, F. \& Xu, J. 2014. The protective 
effect of caffeic acid against inflammation injury of primary bovine mammary epithelial cells induced by lipopolysaccharide. Journal of Dairy Sciences, 97: 2856-2865.

Lou, Z., Wang, H., Rao, S., Sun, J., Ma, C. \& Li, J. 2012. p-Coumaric acid kills bacteria through dual damage mechanisms. Food Control, 25, 550-554.

Magaldi, S., Mata-Essayag, S., De Capriles, C.H., Perez, C., Colella, M., Olaizola, C. \& Ontiveros, Y. 2004. Well diffusion for antifungal susceptibility testing. International Journal of Infectious Diseases, 8: 39-45.

Manjunathan, J. \& Kaviyarasan, V. 2010. Solvent based effectiveness of antibacterial activity of edible mushroom Lentinus tuberregium (Fr.). International Journal of PharmTech Research, 2: 1910-1912.

Masri, H.J.M.H.J., Maftoun, P.M.P., Malek, R.A., Boumehira, A.Z., Pareek, A., Hanapi, S.Z., Ling, O.M. \& El Enshasy, H. 2017. The edible mushroom Pleurotus spp.: ii. medicinal values. International Journal of biotechnology for wellness industries, 6: 1-11.

Mattila, P., Könkö, K., Eurola, M., Pihlava, J.-M., Astola, J., Vahteristo, L., Hietaniemi, V., Kumpulainen, J., Valtonen, M. \& Piironen, V. 2001. Contents of vitamins, mineral elements, and some phenolic compounds in cultivated mushrooms. Journal of Agriculture and Food Chemistry, 49: 2343-2348.

Naczk, M. \& Shahidi, F. 2004. Extraction and analysis of phenolics in food. Journal of Chromatography A,1054: 95-111.

Naegele, E. 2012. Qualitative \& quantitative determination of phenolic antioxidant compounds in red wine and fruit juice with the Agilent 1290 Infinity 2D-LC Solution. Agilent Application Note, Publication Number - 5991$0426 \mathrm{EN}$.

Oke, F. \& Aslim, B. 2011. Protective effect of two edible mushrooms against oxidative cell damage and their phenolic composition. Food Chemistry, 128: 613-619.

Ouyang, J., Sun, F., Feng, W., Sun, Y., Qiu, X., Xiong, L., Liu, Y. \& Chen, Y. 2016. Quercetin is an effective inhibitor of quorum sensing, biofilm formation and virulence factors in Pseudomonas aeruginosa. Journal of Applied Microbiology,120: 966-974.
Oyaizu, M. 1986. Studies on products of browning reaction: antioxidative activity of products of browning reaction prepared from glucosamine. Japanese Journal of Nutrition, 44: 307315.

Palacios, I., Lozano, M., Moro, C., D’arrigo, M., Rostagno, M., Martínez, J., García-Lafuente, A., Guillamón, E. \& Villares, A. 2011. Antioxidant properties of phenolic compounds occurring in edible mushrooms. Food Chemistry, 128: 674-678.

Pandey, V.V., Kumari, A., Kumar, M., Saxena, J., Kainthola, C. \& Pandey, A. 2018. Mushroom cultivation: Substantial key to food security. Journal of Applied and Natural Science,10: 1325-1331.

Park, J.S., Rho, H.S., Kim, D.H. \& Chang, I.S. 2006. Enzymatic preparation of kaempferol from green tea seed and its antioxidant activity. Journal of Agriculture and Food Chemistry, 54: 2951-2956.

Parola, S., Chiodaroli, L., Orlandi, V., Vannin, C. \& Panno, L. 2017. Lentinula edodes and Pleurotus ostreatus: functional food with antioxidant-antimicrobial activity and an important source of Vitamin D and medicinal compounds. Functional Foods in Health and Disease, 7: 773-794.

Podda, M., Weber, C., Traber, M.G. \& Packer, L. 1996. Simultaneous determination of tissue tocopherols, tocotrienols, ubiquinols, and ubiquinones. Journal of Lipid Research, 37: 893-901.

Puttaraju, N.G., Venkateshaiah, S.U., Dharmesh, S.M., Urs, S.M.N. \& Somasundaram, R. 2006. Antioxidant activity of indigenous edible mushrooms. Journal of Agriculture and Food Chemistry, 54: 9764-9772.

Reddy, C. A. \& Mathew, Z . 2001. Bioremediation Potential of White Rot Fungi. In: Fungi in Bioremediation, G.M. Gadd, (Ed.), Cambridge University Press, London, pp: 52-78.

Roncero-Ramos, I. \& Delgado-Andrade, C. 2017. The beneficial role of edible mushrooms in human health. Current Opinion in Food Science, 14: 122-128.

Sajitha Lulu, S., Thabitha, A., Vino, S., Mohana Priya, A. \& Rout, M. 2016. Naringenin and quercetin-potential anti-HCV agents for NS2 protease targets. Natural Product Research, 30: $464-468$. 
Sharma, S., Yadav, R.K.P. \& Pokhrel, C.P. 2013. Growth and yield of oyster mushroom (Pleurotus ostreatus) on different substrates. Journal of New Biology Reports, 2: 03-08.

Singleton, V.L. \& Rossi, J.A. 1965. Colorimetry of total phenolics with phosphomolybdic-phosphotungstic acid reagents. American Journal of Enology and Viticulture,16: 144-158.

Sudha, G., Vadivukkarasi, S., Shree, R.B.I. \& Lakshmanan, P. 2012. Antioxidant activity of various extracts from an edible mushroom Pleurotus eous. Food Science and Biotechenology, 21: 661-668.

Tsai, S.-Y., Huang, S.-J. \& Mau, J.-L. 2006. Antioxidant properties of hot water extracts from Agrocybe cylindracea. Food Chemistry, 98: 670-677.

Vamanu, E., Ene, M., Vamanu, A., Smarandache, D., Sârbu, I., Popa, O., Băbeanu, N., Nita, S. \& Veaceslav, B. 2011. Antioxidant and antibacterial properties of the extracts from Pleurotus ostreatus EVFB1 and EVFB4. Romanian Biotechnological Letters, 16. 41.

Vaz, J.A., Barros, L., Martins, A., Santos-Buelga, C., Vasconcelos, M.H. \& Ferreira, I.C. 2011. Chemical composition of wild edible mushrooms and antioxidant properties of their water soluble polysaccharidic and ethanolic fractions. Food Chemistry,126: 610-616.

Velkov, Z., Balabanova, E. \& Tadjer, A. 2007. Radical scavenging activity prediction of $o$-coumaric acid thioamide. Journal of Molecular Structure: Theochem, 821: 133-138.

Venkatakrishnan, V., Shenbhagaraman, R., Kaviyarasan, V., Gunasundari, D., Radhika, K., Dandapani, R. \& Jagadish, L.K. 2010. An- tioxidant and antiproliferative effect of Pleurotus ostreatus. Journal of Phytology, 2: 022028.

Venturini, M., Rivera, C., Gonzalez, C. \& Blanco, D. 2008. Antimicrobial activity of extracts of edible wild and cultivated mushrooms against foodborne bacterial strains. Journal of Food Protection, 71: 1701-1706.

Vieira, P.A.F., Gontijo, D.C., Vieira, B.C., Fontes, E.A., de Assunção, L.S., Leite, J.P.V., Oliveira, M.G.d.A. \& Kasuya, M.C.M. 2013. Antioxidant activities, total phenolics and metal contents in Pleurotus ostreatus mushrooms enriched with iron, zinc or lithium. LWT-Food Science and Technology, 54: 421-425.

Yen, G.C., Duh, P.D. \& Tsai, C.L. 1993. Relationship between antioxidant activity and maturity of peanut hulls. Journal of Agricultural and Food Chemistry, 4:67-70.

Younis, A.M., Wu, F.-S. \& El Shikh, H.H. 2015. Antimicrobial activity of extracts of the oyster culinary medicinal mushroom Pleurotus ostreatus (higher basidiomycetes) and identification of a new antimicrobial compound. International Journal of Medicinal Mushrooms, 17:579-590.

Zeng, Y., Nikitkova, A., Abdelsalam, H., Li, J. \& Xiao, J. 2019. Activity of quercetin and kaemferol against Streptococcus mutans biofilm. Archives of Oral Biology, 98: 9-16.

Zou, Y., Lu, Y.\& Wei, D. 2004. Antioxidant activity of a flavonoid-rich extract of Hypericum perforatum L. in vitro. Journal of Agriculture and Food Chemistry, 52: 5032-5039. 


\section{استخلام المخلفات الزراعية لإنتاج فطر المحار (Pleurotus ostreatus)

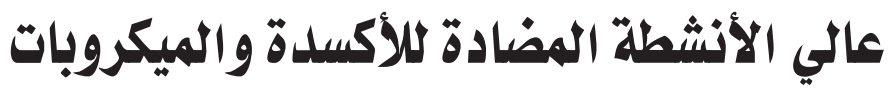

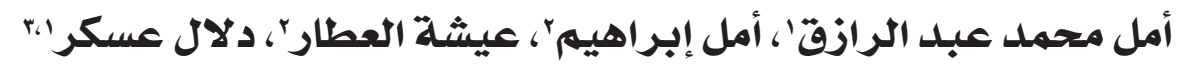

- قسم علوم وتقنية الأغذية -كلية الزراعة (الشاطبى) - جامعة الإسكندرية

r- قسى علوم وتقنية الألبان -كلية الزراعة (الشاطبى) - جامعة الإسكندرية r- قسيم علوم المواد والهندسة - جامعة تورنتو - كندا

يعتبر المشروم المحارى (Pleurotus ostreatus) مصدرًا جيدًا للمركبات النشطة حيويا والتي لها فوائد

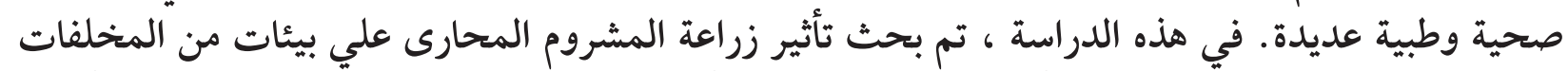

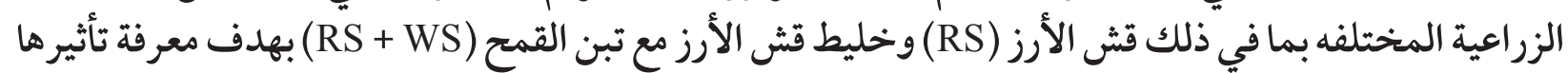

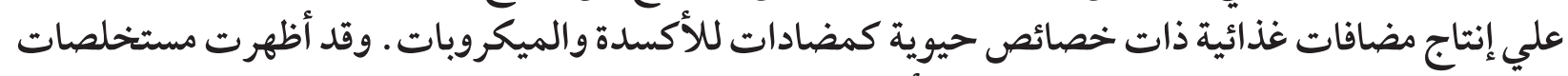

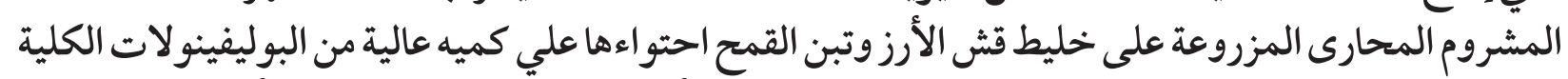

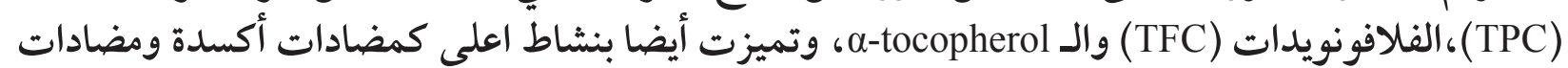

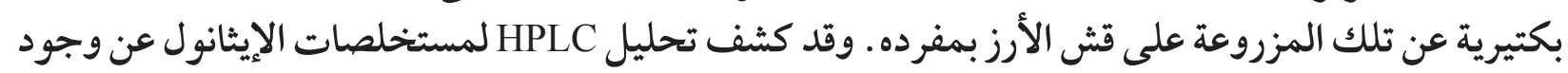

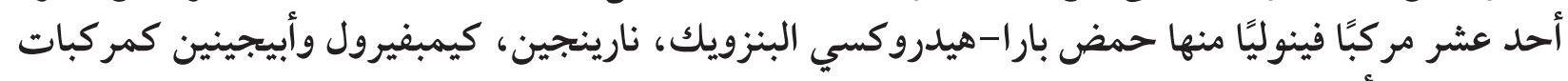

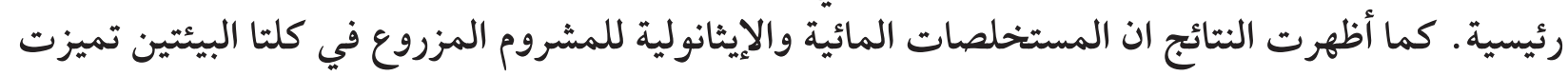

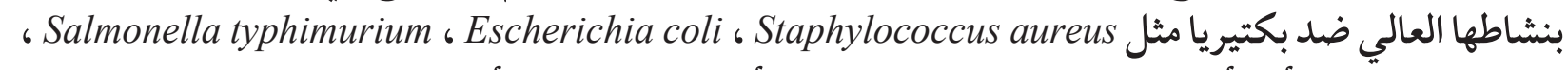
في حين لم يلآحظ أي تأثير مثبط على Bacillus cereus. أشارت النتائج إلى أن زراعة S. ostreatus ،

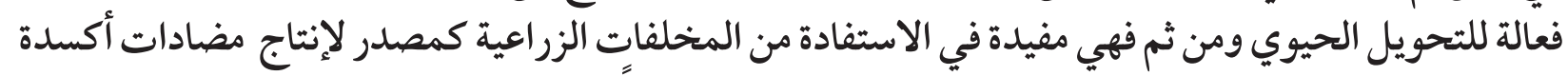

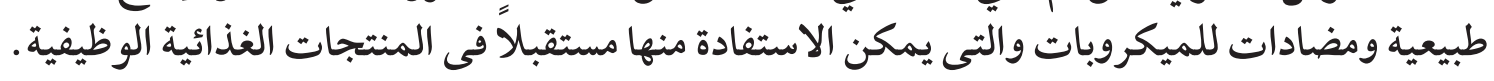


